\title{
Protein-energy supplementation for lambs: feed intake, ingestive behavior, rumen parameters and nutrient digestibility
}

\section{Suplementação proteico-energética para cordeiros: consumo, comportamento ingestivo, parâmetros ruminais e digestibilidade de nutrientes}

\author{
Pâmila Carolini Gonçalves da Silva ${ }^{1}$; Camila Celeste Brandão Ferreira Ítavo²; \\ Luís Carlos Vinhas Ítavo ${ }^{2 *}$; Maria da Graça Morais ${ }^{2}$; Jonilson Araújo da Silva ${ }^{1}$; \\ Natália da Silva Heimbach ${ }^{1}$; Gleice Kelli Ayardes de Melo; \\ Marlova Cristina Mioto da Costa $^{1}$
}

\begin{abstract}
The study evaluated the effects of dietary protein-energy supplementation on feed intake, ingestive behavior, rumen parameters and nutrient digestibility in lambs. Four castrated lambs with $31.9 \mathrm{~kg}$ mean body weight and fistulated rumen were tested. distributed into latin square design $(4 \times 4)$, four treatments were tested over four periods of time: no supplementation (control) or with supplementation at 8,16 and $24 \mathrm{~g} \mathrm{~kg}^{-1}$ body weight. The supplement (soybean meal, soybean hulls, ground corn and minerals) was provided with roughage (Tifton Bermudagrass, Cynodon spp., hay), which was offered ad libitum once a day, at $8 \mathrm{~h} 00$. In treatments receiving 0 (control), 8,16 and $24 \mathrm{~g} \mathrm{~kg}^{-1}$ supplementation, dry matter intake was $685.26,742.86,842.51$ and $1013.33 \mathrm{~g} \mathrm{day}^{-1}$, crude protein intake was 80.18, 95.98, 118.64, 150.14 $\mathrm{g} \mathrm{day}^{-1}$ and metabolizable energy intake $1.55,1.91,2.31$ and $2.98 \mathrm{~g}$ day $^{-1}$, respectively. Treatments receiving the highest supplementation levels spent less time with rumination and feeding and rested for longer $(\mathrm{P}<0.05)$. Protein-energy supplementation level did not affect rumen parameters. Average rumen $\mathrm{pH}$ was 6.3 and rumen ammonia nitrogen $165 \mathrm{mg} \mathrm{dL}^{-1}$; both were affected by sampling time. Supplementation levels until $24 \mathrm{~g} \mathrm{~kg}^{-1} \mathrm{BW}$ improves feed intake and nutrient digestibility linearly and changes ingestive behavior, lowering rumination time without affecting rumen parameters.
\end{abstract}

Key words: Diet. Ammonia nitrogen. Rumen $\mathrm{pH}$. Rumination. Sheep.

\section{Resumo}

Objetivou-se avaliar o efeito da suplementação proteico-energética sobre o consumo, comportamento ingestivo, parâmetros ruminais e digestibilidade de nutrientes em ovinos. Foram utilizados quatro cordeiros castrados, com peso médio de $31,9 \mathrm{~kg}$, fistulados no rúmen. O delineamento foi quadrado latino $(4 \mathrm{x} 4)$, sendo 4 tratamentos e 4 períodos: controle (sem suplementação) e suplementados com 8 , 16 e $24 \mathrm{~g} \mathrm{~kg}^{-1}$ do peso corporal (PC). O volumoso, feno de capim-tifton (Cynodon spp.), foi fornecido à vontade e o suplemento era constituído por farelo de soja, casca de soja, milho moído e minerais. Os

1 Discentes, Faculdade de Medicina Veterinária e Zootecnia, FAMEZ, Universidade Federal de Mato Grosso do Sul, UFMS, Campo Grande, MS, Brasil. E-mail: carolinigoncalves@zootecnista.com.br; jonilsonsilva@zootecnista.com.br; nat_heimbach@ hotmail.com; gleiceayardes@gmail.com; marlovamioto@hotmail.com

2 Profs., FAMEZ, UFMS, Campo Grande, MS, Brasil. E-mail: camila.itavo@ufms.br; luis.itavo@ufms.br; morais.mariazinha@ gmail.com

* Author for correspondence

Received: Sept. 23, 2016 Approved: Mar. 29, 2017 
alimentos foram fornecidos uma vez ao dia, às 8 horas. Nos tratamentos que receberam 0 (controle), 8,16 e $24 \mathrm{~g} \mathrm{~kg}^{-1}$ de suplementação, o consumo de matéria seca foi igual a 685,$26 ; 742,86 ; 842,51$ e $1013,33 \mathrm{~g} \mathrm{dia}^{-1}$, o consumo de proteína bruta igual 80,18; 95,98; 118,64; $150,14 \mathrm{~g} \mathrm{dia}^{-1}$, o consumo de energia metabolizável igual a 1,55; 1,91; 2,31 e 2,98 para os tratamentos controle, 8,16 e $24 \mathrm{~g} \mathrm{~kg}^{-1} \mathrm{PC}$, respectivamente. Maiores níveis de suplementação proporcionaram menor tempo gasto com ruminação e alimentação e maior período em ócio $(\mathrm{P}<0.05)$. Não houve efeito do nível de suplementação proteicoenergética sobre os parâmetros ruminais. $\mathrm{O} \mathrm{pH}$ ruminal e o nitrogênio amoniacal ruminal apresentaram médias de 6,3 e $16,5 \mathrm{mg} \mathrm{dL}^{-1}$, respectivamente, e foram influenciados pelo tempo de coleta. A suplementação até $24 \mathrm{~g} \mathrm{~kg}^{-1}$ PC favorece linearmente a melhora do consumo e digestibilidade dos nutrientes e altera o comportamento ingestivo com menor tempo gasto com ruminação sem alteração dos parâmetros ruminais.

Palavras-chave: Dieta. Nitrogênio amoniacal. Ovinos. Ph ruminal. Ruminação.

\section{Introduction}

Diet supplementation is widely used in sheep husbandry to enhance production and make up for the nutritional deficit of grasses in the dry season (CARVALHO et al., 2011). It is an alternative to minimize the effects of changes in forage production throughout the year, waiting to supply the deficiency of quantity or quality forage (VOLTOLINI et al., 2011). However, supplementation procedures are still essentially empirical, given that little is known about the requirement of animals in tropical conditions and what are the effects of the grains introduction in the diet for sheep on ruminal parameters, intake and digestibility.

Dietary nitrogen content must be balanced to avoid disturbances in rumen environment. In this respect, synchronization between energy availability and diet nitrogen is known to be one of the most important factors determining the efficiency of nitrogen use by rumen microorganisms (NRC, 2007). In addition, ruminal fermentation depends on the nature of the diet, which indirectly leads to selection of rumen microorganisms by a reduction or increase in $\mathrm{pH}$, ammonia nitrogen $\left(\mathrm{NH}_{3}-\mathrm{N}\right)$ concentration and volatile fatty acids (VFA).

It is common for animals that exclusively feed on roughage to not meet minimum nutritional requirements and therefore do not reach their growth potential because of ruminal fill with high fiber content intake diet, which moves slowly through the gastrointestinal tract, thereby limiting feed intake. Diets containing protein-energy supplements increase total dry matter intake, lowering roughage intake and increasing voluntary nutrient intake, which can improve performance (JOCHIMS et al., 2010). On the other hand, although supplements can attenuate nutritional deficiency arising from poor quality pastures, they may also raise production costs and even make sheep husbandry unfeasible if used in excess (VOLTOLINI et al., 2009). Accordingly, the present study evaluated protein-energy supplementation levels for lambs by assessing their ingestive behavior, rumen parameters and nutrient digestibility.

\section{Materials and Methods}

The experiment was conducted at the Laboratory of Animal Metabolism of the Faculty of Veterinary Medicine and Animal Science (FAMEZ) of the Federal University of Mato Grosso do Sul (UFMS) and at the Laboratory of Biotechnology Applied to Animal Nutrition of the Dom Bosco Catholic University (UCDB) in Campo Grande MS, Brazil. This work has been approved by Ethical Committee for use of animal in experiments (protocol n.218/2009).

Four rumen-fistulated, castrated Texel crossbred lambs of the same age $(18 \mathrm{mo})$ and mean weight 
of $31.9 \pm 3.07 \mathrm{~kg}$ were used. The animals were housed in individual $3 \mathrm{~m}^{2}$ stalls with slatted floor, waterer and food trough (for food and mineral supplementation).

Before experiment onset, the animals were treated with anthelmintics for parasite control, which was monitored throughout the experiment by fecal EPG (eggs per gram).

Ground Bermuda Tifton-85 hay (Cynodon spp.) passed through a $0.5 \mathrm{~cm}$ mesh screen was provided as roughage. The protein-energy supplement contained soybean meal, soybean hulls, ground corn and mineral premix for sheep (Table 1).

The animals were distributed into a latin square design, and four diets were tested, a control diet (without concentrate supplementation) and three levels of protein-energy supplementation: 8,16 and $24 \mathrm{~g} \mathrm{~kg}^{-1} \mathrm{BW}$. The feed (roughage and supplement) was offered once a day, at $8 \mathrm{~h} 00$ in separate hoppers, enabling control of the feed intake individually.

Diet leftovers were weighed daily and roughage supply was adjusted accordingly $100 \mathrm{~g} \mathrm{~kg}^{-1}$ of leftover (natural matter basis), which characterizes ad libitum forage intake.

Each experimental period lasted 14 days, the first 7 days for animals to adjust to the experimental treatments and the remaining 7 days to collect behavioral data and samples of feeds, orts, feces and rumen fluid. On day 8 , the ingestive behavior was observed. On day 10 to day 12 were made as collections of feces and on day 13 and 14 collection of rumen fluid.

To determine digestibility in each period, fecal collection bags were fitted to lambs to allow total fecal collection for $48 \mathrm{~h}$, as described by Ítavo et al. (2002). Feces were collected manually before feeding of animals, then weighing, homogenized and sampled $100 \mathrm{~g} \mathrm{~kg}^{-1}$ of the fecal matter to integrate a composite sample for each period and treatment. Samples were frozen for subsequent analysis. After diets and leftovers were quantified, composite samples of these materials were formed to determine intakes for each period.

During the collection period, feed provided and leftovers were collected manually and sampled for further analysis. Feeds, orts and feces were predried in a forced ventilation oven at $55^{\circ} \mathrm{C}$ for $96 \mathrm{~h} 00$ and ground and passed through a $1 \mathrm{~mm}$ mesh screen for determination of dry matter (DM), organic matter $(\mathrm{OM})$, crude protein $(\mathrm{PB})$ and ether extract (EE) (Table 1) in accordance with AOAC methods 920.15, 932.05, 976.05 and 920.39, respectively (AOAC, 2000). Neutral detergent fiber (NDF) and acid detergent fiber (ADF) levels were determined according to Goering and Van Soest (1970), and protein-energy supplement analyzed with sulfite without thermostable amylase. Digestible energy (DE) and metabolizable energy (ME) levels were estimated according to Sniffen et al. (1992). One kilogram of total digestible nutrients (TDN) was considered to contain 4.409 Mcal of DE, with 1 Mcal corresponding to $0.82 \mathrm{Mcal}$ ME.

In each period, ingestive behavior was observed every 10 min by the instant scan sampling technique, as described by Altmann (1974) and Martin and Bateson (1993). The observations lasted $24 \mathrm{~h}$, from $8 \mathrm{~h} 00$ (after feed provision) to $8 \mathrm{~h} 00$ of the following day (before feed provision) totalizing $96 \mathrm{~h}$ of observation, rumination, eating, drinking, resting and locomotion were recorded.

Feed and rumination efficiency of DM and NDF were obtained by dividing the intakes of these products by total ingestion and rumination time, respectively.

Rumen fluid samples were collected before feeding and 1, 2, 3, 4, 5, 6, 8, 10 and $12 \mathrm{~h}$ after feed supply. For each collection, a significant sample of rumen content was manually collected using a ruminal cannula and immediately filtered in cotton fabric to obtain nearly $200 \mathrm{~mL}$ of filtered rumen fluid. After fluid $\mathrm{pH}$ was measured, a $50 \mathrm{~mL}$ aliquot was separated, added with $1 \mathrm{~mL} \mathrm{1:1} \mathrm{hydrochloric}$ acid and stored in plastic tubes at $20^{\circ} \mathrm{C}$ to be used 
for subsequent ammonia nitrogen determination (FENNER, 1965).

The treatments were arranged in a Latin square design. Data were analyzed by the one-way analysis of variance dunnet- test and regression tests $(\mathrm{P}<0.05)$. Data on $\mathrm{pH}$ and rumen ammonia-N levels were analyzed in a split-plot arrangement with treatments as plots and collection time (h) as subplots.

\section{Result and Discussion}

Nutrient intakes increased linearly $(\mathrm{P}<0.05)$ with supplementation, but roughage DM intake decreased $(\mathrm{P}<0.05)$ because of lower roughage fiber intake (Table 2). The time spent on rumination increased reflecting improved efficiency of rumination but not the time spent on eating, resting and locomotion. Lambs receiving supplement at $8 \mathrm{~g} \mathrm{~kg}^{-1} \mathrm{BW}$ spent more time on rumination (Table 2 ).

Dry matter intake was below $30 \mathrm{~g} \mathrm{~kg}^{-1} \mathrm{BW}$, the level recommended by the NRC (2007) for lambs, indicating that DM intake was limited in the present study. The higher the fiber content in the diet, the faster the rumen fill and animal satiation (GERON et al., 2013; RIBEIRO et al., 2009; VAN SOEST, 1994;). This was observed in the present study because DM intake increased with supplementation level, and feed intake was lower in non-supplemented lambs (Table 1).

The total NDF intake (roughage + concentrate supplement) did not differ between treatments (485.44 $\mathrm{g} \mathrm{dia}^{-1}$ ). However, considering roughageNDF participation in the diet, its consumption decreased $\left(b=-13.166 \mathrm{~g} \mathrm{dia}^{-1}\right)$ with an increase in concentrate supplementation levels. Therefore, in the absence of readily available substrates, roughage alone filled the rumen, but this effect decreased with supplementation, increasing feed intake.

Mertens (1994) reported that DM intake decreases with an increase in diet fiber content in ruminants. Total NDF intake in the present study on average $15.74 \mathrm{~g} \mathrm{~kg}^{-1} \mathrm{BW}$, was slightly higher than the $12 \mathrm{~g} \mathrm{NDF} \mathrm{kg}^{-1}$ BW cited by Mertens (1994). This level corresponds to the physical limit of feed intake, reinforcing the fact that an increase in concentrate supplement levels decreases fiber intake in relation to DM intake.

The use of supplementation provides different effects associated with feed intake or replacement. It was observed in this study, quality the protein supplementation level of $13.48 \mathrm{~g} \mathrm{~kg}^{-1} \mathrm{BW}$ showed an additive effect, namely the complete supplement the shortage of nutrients. With supplementation above that level the animal has replaced the bulky for concentrate. In protein-energy supplementation field condition in $13.48 \mathrm{~g} \mathrm{~kg}^{-1} \mathrm{BW}$ provides a better use of roughage, as this is the cheapest portion of animal feed, more cost-effective, also other factors may be considered animal grazing and stocking rate and forage supply.

The use of protein-energy supplements linearly affected $(\mathrm{P}<0.05)$ the coefficients of nutrient digestibility (Table 3 ). Table 2 shows an increase in nutrient intake $(\mathrm{P}<0.05)$. In a study on the replacement of coastcross hay by soybean hulls (at 12.5, 25 and $37.5 \mathrm{~g} \mathrm{DM} \mathrm{kg} \mathrm{BW),} \mathrm{Morais}$ et al. (2006) also found a linear increase in digestibility coefficients with supplementation. For a supplementation level of $12.5 \mathrm{~g} \mathrm{~kg}^{-1}$, they report apparent digestibility of $758.8 \mathrm{~g} \mathrm{~kg}^{-1}$ for DM, $772.3 \mathrm{~g}$ $\mathrm{kg}^{-1}$ for OM, 690.0 $\mathrm{g} \mathrm{kg}^{-1}$ for NDF and $695.1 \mathrm{~g} \mathrm{~kg}^{-1}$ for ADF, which are close to the values obtained in the present study. These authors observed that when forage is not completely replaced by concentrate, i.e. the diet contains minimal forage content, feed retention time in the rumen increases, possibly improving nutrient digestibility.

The longer rumination time enhanced dietary energy utilization, improving nutrient digestibility, as shown in Table 2. Supplementation likely increased digestion kinetics and decreased rumen fill, allowing an increase in DM intake, protein and readily available energy (Table 2 ). 
Table 1. Ingredients and chemical composition of the diets.

\begin{tabular}{|c|c|c|c|c|c|c|}
\hline \multirow{2}{*}{ Chemical composition } & \multirow{2}{*}{$\begin{array}{c}\text { Bermudagrass } \\
\text { Tifton hay }\end{array}$} & \multirow{2}{*}{$\begin{array}{l}\text { Protein-energy } \\
\text { supplement }{ }^{1}\end{array}$} & \multicolumn{4}{|c|}{ Diets } \\
\hline & & & 0 & 8 & 16 & 24 \\
\hline Dry matter ( $\mathrm{g} \mathrm{kg}^{-1}$ fresh weight) & 913.74 & 911.21 & 913.74 & 912.92 & 912.31 & 911.93 \\
\hline Crude protein $\left(\mathrm{g} \mathrm{kg}^{-1} \mathrm{DM}\right)$ & 108.42 & 160.65 & 108.42 & 125.27 & 138.01 & 145.72 \\
\hline Neutral detergent fiber $\left(\mathrm{g} \mathrm{kg}^{-1} \mathrm{DM}\right)$ & 834.96 & 419.34 & 834.96 & 700.87 & 599.46 & 538.11 \\
\hline Acid detergent fiber $\left(\mathrm{g} \mathrm{kg}^{-1} \mathrm{DM}\right)$ & 471.89 & 297.21 & 471.89 & 415.53 & 372.91 & 347.13 \\
\hline Ether extract $\left(\mathrm{g} \mathrm{kg}^{-1} \mathrm{DM}\right)$ & 12.56 & 23.61 & 12.56 & 16.13 & 18.82 & 20.45 \\
\hline Metabolizable energy (Mcal day) & 1.55 & - & 1.55 & 1.91 & 2.31 & 2.99 \\
\hline
\end{tabular}

${ }^{1} 401.7 \mathrm{~g}$ soybean hulls, $400 \mathrm{~g}$ ground corn, $131.2 \mathrm{~g}$ soybean meal and $68.1 \mathrm{~g}$ mineral premix (per kilogram of DM); ${ }^{2}$ Metabolizable energy $=[$ digestible $\mathrm{CP}+$ digestible NDF + digestible non fiber carbohydrates $+($ digestible EE $\mathrm{x} 2.25)$ $* 0.82 * 4.41]$.

Table 2. Mean feed intake in lambs fed diets with different protein-energy balance.

\begin{tabular}{|c|c|c|c|c|c|c|c|c|}
\hline & \multicolumn{4}{|c|}{ Supplementation level $\left(\mathrm{g} \mathrm{kg}^{-1} \mathrm{BW}\right)$} & \multirow{2}{*}{$\mathrm{P}$} & \multirow{2}{*}{ SEM } & \multirow{2}{*}{$\begin{array}{l}\text { Regression Equation } \\
\text { (y) }\end{array}$} & \multirow{2}{*}{$\mathrm{R}^{2}$} \\
\hline & 0 & 8 & 16 & 24 & & & & \\
\hline Variable & \multicolumn{4}{|c|}{ Intakes } & & & & \\
\hline Roughage-DM (g day) & 685.26 & 503.47 & 365.14 & 289.58 & 0.001 & 79.028 & $663.75-17.77 * \mathrm{~L}$ & 0.53 \\
\hline Concentrate-DM (g day) & 0.00 & 239.79 & 477.38 & 723.76 & $<0.001$ & 23.084 & $-12.30+32.39 * \mathrm{~L}$ & 0.97 \\
\hline Roughage-CP (g day) & 78.50 & 57.46 & 41.94 & 33.86 & 0.001 & 8.952 & $76.34-2.03 * \mathrm{~L}$ & 0.54 \\
\hline Concentrate-CP (g day) & 0.00 & 38.52 & 76.70 & 116.28 & $<0.001$ & 3.709 & $-1.98+5.20 * \mathrm{~L}$ & 0.97 \\
\hline Roughage-NDF (g day) & 492,43 & 372.14 & 270.00 & 202.95 & 0.002 & 64.126 & $485.74-13.166 * \mathrm{~L}$ & 0.49 \\
\hline Concentrate-NDF (g day) & 0.00 & 100.55 & 200.19 & 303.50 & $<0.001$ & 9.680 & $-5.16+13.58 * \mathrm{~L}$ & 0.97 \\
\hline Activity & \multicolumn{4}{|c|}{ Behavioral activities } & & & & \\
\hline Eating $(0-1)$ & 0.23 & 0.22 & 0.22 & 0.16 & 0.307 & 0.014 & $\mathrm{NS}$ & \\
\hline Rumination(0-1) & 0.24 & 0.28 & 0.19 & 0.16 & 0.035 & 0.019 & $30.59-3.56 * \mathrm{SL}$ & 0.68 \\
\hline Resting (0-1) & 0.43 & 0.41 & 0.46 & 0.59 & 0.180 & 0.032 & NS & \\
\hline Locomotion (0-1) & 0.09 & 0.09 & 0.12 & 0.08 & 0.308 & 0.029 & NS & \\
\hline Drinking $(0-1)$ & 0.01 & 0.01 & 0.05 & 0.04 & 0.457 & 0.014 & NS & \\
\hline $\begin{array}{l}\text { Feeding efficiency ( } \mathrm{g} \text { DM } \\
\min ^{-1} \text { ) }\end{array}$ & 2.0 & 2.3 & 5.6 & 5.1 & 0.034 & 0.469 & $5.34+0.16 * \mathrm{SL}$ & 0.76 \\
\hline $\begin{array}{l}\text { Rumination efficiency ( } \mathrm{g} \\
\mathrm{DM} \min ^{-1} \text { ) }\end{array}$ & 1.9 & 1.8 & 3.1 & 5.4 & 0.005 & 0.497 & $1.34+0.19 * \mathrm{SL}$ & 0.83 \\
\hline
\end{tabular}

$\mathrm{DM}=$ dry matter, $\mathrm{CP}=$ crude protein, $\mathrm{NDF}=$ neutral detergent fiber, $\mathrm{ADF}=$ acid detergent fiber, $\mathrm{EE}=\mathrm{ether}$ extract, $\mathrm{ME}$ $=$ metabolizable energy [digestible $\mathrm{CP}+$ digestible NDF + digestible non fiber carbohydrates $+($ digestible EE $\mathrm{x} 2.25)$

$* 0.82 * 4.41]$. $\mathrm{L}=$ level of supplementation. $\mathrm{NS}=$ not significant, $\mathrm{SEM}=$ standard error of mean. 
Table 3. Mean dry matter intake, apparent digestibility of nutrients and metabolizable energy of lambs fed diets with different protein-energy balance.

\begin{tabular}{|c|c|c|c|c|c|c|c|c|}
\hline \multirow{2}{*}{ Digestibility } & \multicolumn{4}{|c|}{ Supplementation level ( $\left.\mathrm{g} \mathrm{kg}^{-1} \mathrm{BW}\right)$} & & \multirow{2}{*}{ SEM } & \multirow{2}{*}{ Regression Equation (y) } & \multirow{2}{*}{$\mathrm{R}^{2}$} \\
\hline & 0 & 8 & 16 & 24 & & & & \\
\hline DMI (g day) & 685.26 & 736,99 & 838.81 & 999.17 & 0.015 & 87.376 & $655.90+13.84 * \mathrm{SL}$ & 0.35 \\
\hline $\mathrm{DM}\left(\mathrm{g} \mathrm{kg}^{-1}\right)$ & 61.90 & 73.14 & 76.83 & 85.28 & 0.001 & 4.343 & $62.85+0.99 * \mathrm{SL}$ & 0.53 \\
\hline $\mathrm{CP}\left(\mathrm{g} \mathrm{kg}^{-1}\right)$ & 73.87 & 75.62 & 81.78 & 86.74 & 0.011 & 3.567 & $72.62+0.60 * \mathrm{SL}$ & 0.38 \\
\hline $\operatorname{NDF}\left(\mathrm{g} \mathrm{kg}^{-1}\right)$ & 68.99 & 73.15 & 75.39 & 82.81 & 0.020 & 3.858 & $68.42+0.58 * \mathrm{SL}$ & 0.33 \\
\hline $\operatorname{ADF}\left(\mathrm{g} \mathrm{kg}^{-1}\right)$ & 57.77 & 66.44 & 70.31 & 79.39 & 0.006 & 4.994 & $57.89+0.92 * \mathrm{SL}$ & 0.43 \\
\hline $\mathrm{EE}\left(\mathrm{g} \mathrm{kg}^{-1}\right)$ & 56.87 & 67.05 & 79.23 & 86.77 & $<0.001$ & 5.184 & $56.63+1.38 * \mathrm{SL}$ & 0.62 \\
\hline $\operatorname{ME}\left(\right.$ Mcal kg DM $\left.^{-1}\right)$ & 2.25 & 2.56 & 2.77 & 3.00 & 0.001 & 0.122 & $2.27+0.03 * \mathrm{SL}$ & 0.63 \\
\hline
\end{tabular}

$\mathrm{DMI}=$ Dry matter intake, $\mathrm{DM}=$ dry matter, $\mathrm{CP}=$ crude protein, $\mathrm{NDF}=$ neutral detergent fiber, $\mathrm{ADF}=$ acid detergent fiber, $\mathrm{EE}=$ ether extract, $\mathrm{ME}=$ metabolizable energy, $\mathrm{SEM}=$ standard error of mean, $\mathrm{SL}=$ supplementation level.

With supplement provision at $8 \mathrm{~g} \mathrm{~kg}^{-1} \mathrm{BW}$, digestibility improved $11 \%$ in relation to the control treatment, and increased a further $3 \%$ with $16 \mathrm{~g} \mathrm{~kg}^{-1}$ BW. This indicates that low dietary concentrate $(8$ $\mathrm{g} \mathrm{kg}^{-1} \mathrm{BW}$ ) provides substrate for microorganism proliferation, enhancing ruminal fermentation and the coefficient of digestibility. Therefore, future investigations on the assessment of animal performance are needed, as well as diet analysis from an economic perspective. These studies may support the selection of production systems that attempt to achieve a bioeconomically optimal condition.

Pompeu et al. (2009) founded that the rumination time of sheep grazing on Tanzania grass was 0.32 , $0.36,0.30$ and 0.31 minutes for supplementation levels of $0,6,12$ and $18 \mathrm{~g} \mathrm{~kg}^{-1}$ BW. These values are above those found in the present study, likely because lambs grazed on pasture grass. Morais et al. (2006) studied sheep fed coastcross hay (Cynodon sp.) as roughage, mixed to soybean hulls at 0 , $12.5,25$ and $37.5 \mathrm{~g} \mathrm{~kg}^{-1} \mathrm{DM}$, and found that those receiving the highest supplement levels spent less time on eating and rumination activities. Soybean hulls contain highly degradable pectin in their cell walls, which improves rumen fermentation pattern because it reduces lactate production (MORAIS et al., 2006).

In the present study, DM intake increased with supplementation $(\mathrm{P}<0.05)$, whereas effective fiber content likely remained unchanged (Table 2). However, the high roughage fiber content in diets with high roughage content stimulates chewing because of the large particle size of these fibers (MACEDO JÚNIOR et al., 2007).

Feed intake was higher at $8 \mathrm{~h} 00$ when feed was supplied, and another feeding peak occurred at 16 h00 (Figure 1). Similarly, Pompeu et al. (2009) founded that lambs receiving supplemented diets exhibited the highest eating activity from $5 \mathrm{~h} 00$ to $8 \mathrm{~h} 00$ and from $14 \mathrm{~h} 00$ to $17 \mathrm{~h} 00$. The animals started to ruminate nearly 4 hours after feed intake peaks (Figure 1). The rest period, was longer from $23 \mathrm{~h} 00$ to $4 \mathrm{~h} 00$. The lambs evaluated by Pompeu et al. (2009) rested longer from $23 \mathrm{~h} 00$ to $2 \mathrm{~h} 00$. Ítavo et al. (2011) also found longer rumination time 4 $\mathrm{h}$ after lambs were fed and at dawn, with resting occurring predominantly at night.

Ruminal $\mathrm{pH}$ and ammonia nitrogen did not change significantly as a function of supplementation levels $(\mathrm{P}>0.05)$, but ruminal $\mathrm{pH}$ linearly decreased over time after feeding $(\mathrm{P}<0.05)$ and ammonia-N showed cubic effect (Table 4). 
Possibly with the use of soybean hulls in the supplement, the increase in potentially digestible fiber in the diet compensates for low saliva production because the fermentation pattern it produces is similar to that obtained with forage. This occurs due to the presence of pectin, which decreases lactate production, thereby contributing to maintaining rumen $\mathrm{pH}$. Rumen $\mathrm{pH}$ changed as a function of sampling time, decreasing after feeding (Table 4). The growth of rumen bacteria through fermentation processes likely decreased $\mathrm{pH}$ over time, but values between 6.5 and 6.8 were suitable for fiber fermentation and digestion (MERTENS, 1979; ØRSKOV, 1982; RODRIGUES et al., 2011; WERNERBACH FILHO, et al., 2006;). However, corroborating other studies on lambs that tested diets increasing levels of concentrate (GERON et al., 2013), minerals, energy and protein associated with Marando grass (CARVALHO et al., 2011), and different levels of sorghum (AGUERRE et al., 2009), rumen $\mathrm{pH}$ did not change as a function of supplementation.

Figure 1. Characterization of daily ingestive behavior as a function of hours after feeding $(8 \mathrm{~h} 00=$ feeding time $)$ and treatment ( 0 corresponds to non-supplemented control; 8, 16 and 24 correspond to daily supplementation levels of 8 , 16 and $\left.24 \mathrm{~g} \mathrm{~kg}^{-1} \mathrm{BW}\right)$.
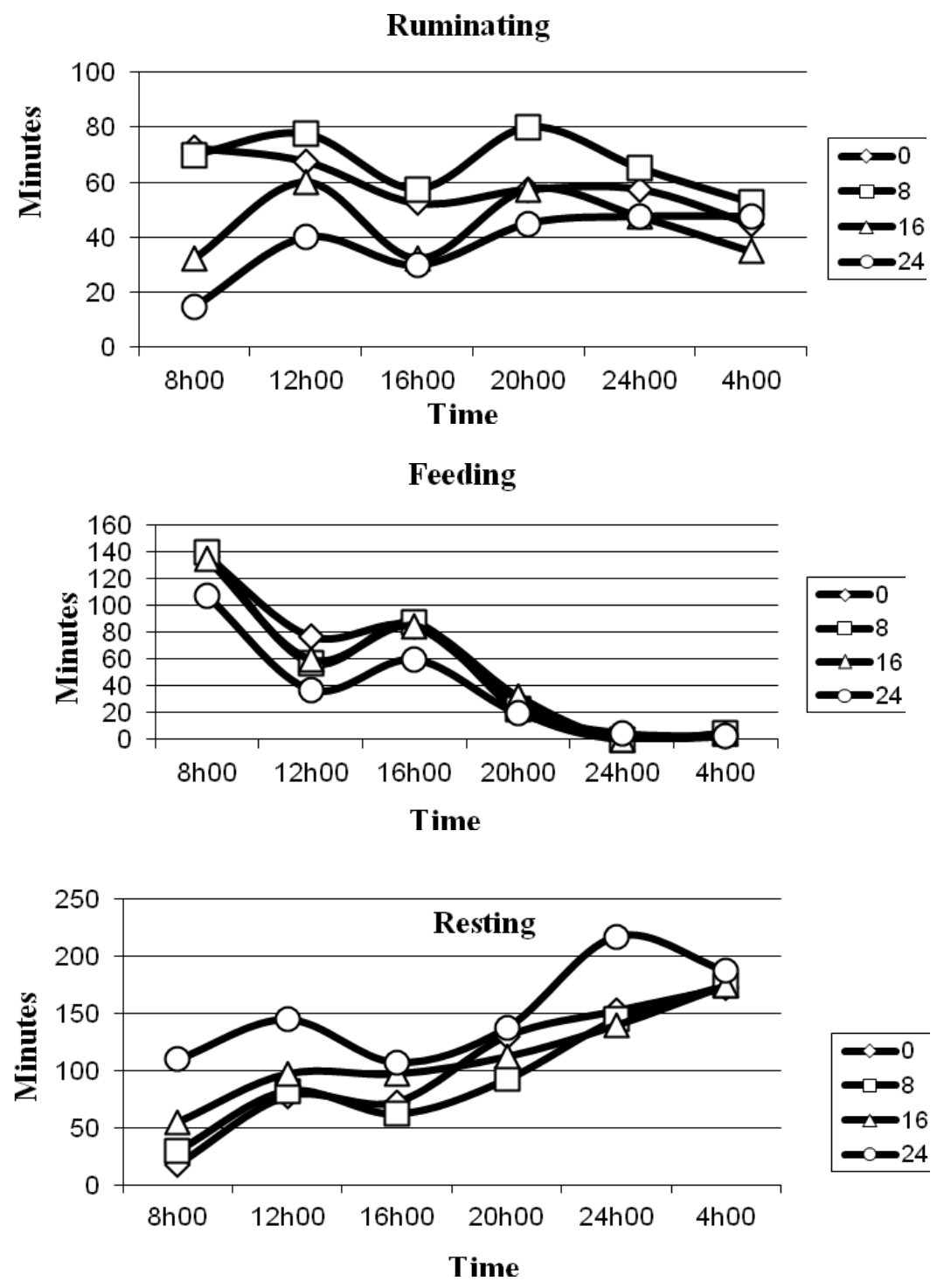
Ammonia nitrogen levels are directly associated to the ingestive behavior of the animals. It decreased in the first hours post feeding, peaked five hours after feeding and then declined. The peak (Figure 1) was triggered by rumination, which started $4 \mathrm{~h}$ after feeding (8h00). This occurs because during rumination lambs recycle large amounts of nitrogen through saliva. In this process, $\mathrm{N}-\mathrm{NH}_{3}$ levels in the rumen are associated with the speed of nitrogen incorporation and release, as well as its assimilation into microbial proteins. Therefore, the decline following the $\mathrm{N}_{-} \mathrm{NH}_{3}$ peak likely results from the increase in microbial protein synthesis by the larger rumen bacterial population.

Table 4. $\mathrm{pH}$ me of rumen fluid and ammonia nitrogen (mg $100 \mathrm{~mL}^{-1}$ of rumen fluid) means of lambs as a function of treatment and time (hours) after feeding.

\begin{tabular}{|c|c|c|c|c|c|c|}
\hline \multirow{2}{*}{ Hours after feed supply } & \multicolumn{4}{|c|}{ Supplementation level $\left(\mathrm{g} \mathrm{kg}^{-1} \mathrm{BW}\right)$} & \multirow{2}{*}{$\mathrm{P}$} & \multirow{2}{*}{ SEM } \\
\hline & 0 & 8 & 16 & 24 & & \\
\hline \multicolumn{7}{|c|}{$\mathrm{pH}$ ruminal } \\
\hline 0 & 6.72 & 6.85 & 6.89 & 6.72 & 0.905 & 0.093 \\
\hline 1 & 6.78 & 6.68 & 6.70 & 6.61 & 0.922 & 0.080 \\
\hline 2 & 6.72 & 6.63 & 6.57 & 6.54 & 0.216 & 0.080 \\
\hline 3 & 6.43 & 6.59 & 6.37 & 6.36 & 0.951 & 0.140 \\
\hline 4 & 6.51 & 6.28 & 6.11 & 6.21 & 0.809 & 0.141 \\
\hline 5 & 6.46 & 6.52 & 6.17 & 6.13 & 0.602 & 0.117 \\
\hline 6 & 6.41 & 6.27 & 6.19 & 6.21 & 0.891 & 0.103 \\
\hline 8 & 6.46 & 5.93 & 5.96 & 6.01 & 0.557 & 0.140 \\
\hline 10 & 6.17 & 5.98 & 5.85 & 5.86 & 0.724 & 0.106 \\
\hline 12 & 5.82 & 5.56 & 5.43 & 5.23 & 0.803 & 0.199 \\
\hline $\mathrm{P}$ & $0.001^{1}$ & $0.003^{2}$ & $0.001^{3}$ & $0.001^{4}$ & & \\
\hline SEM & 0.072 & 0.117 & 0.098 & 0.087 & & \\
\hline Hours after feed supply & \multicolumn{5}{|c|}{ Ammonia nitrogen (mg 100ml of rumen fluid) } & \\
\hline 0 & 24.85 & 19.97 & 23.42 & 24.52 & 0.760 & 1.669 \\
\hline 1 & 16.53 & 20.14 & 16.61 & 17.18 & 0.730 & 1.215 \\
\hline 2 & 11.97 & 13.16 & 9.97 & 13.29 & 0.954 & 1.790 \\
\hline 3 & 13.96 & 14.02 & 15.39 & 13.61 & 0.983 & 1.519 \\
\hline 4 & 8.42 & 6.91 & 8.07 & 8.78 & 0.897 & 0.834 \\
\hline 5 & 23.00 & 22.92 & 27.67 & 23.27 & 0.731 & 1.642 \\
\hline 6 & 17.59 & 18.53 & 18.44 & 16.13 & 0.953 & 1.525 \\
\hline 8 & 12.54 & 14.72 & 16.93 & 14.41 & 0.936 & 2.212 \\
\hline 10 & 23.53 & 21.09 & 22.94 & 19.83 & 0.927 & 1.986 \\
\hline 12 & 8.56 & 10.36 & 9.17 & 7.37 & 0.713 & 0.863 \\
\hline$P$ & $0.001^{5}$ & $0.020^{6}$ & $0.002^{7}$ & $0.002^{8}$ & & \\
\hline SEM & 1.313 & 1.270 & 1.409 & 1.236 & & \\
\hline
\end{tabular}

$\mathrm{SEM}=$ standard error of mean. ${ }^{1} \mathrm{y}=6.791-0.067 *$ time $\left(\mathrm{r}^{2}=0.85\right) ;{ }^{2} \mathrm{y}=6.934-0.099 *$ time $\left(\mathrm{r}^{2}=0.93\right) ;{ }^{3} \mathrm{y}=6.765-0.106 *$ time $\left(\mathrm{r}^{2}=\right.$ $0.93) ;{ }^{4} \mathrm{y}=6.726-0.105 *$ time $\left(\mathrm{r}^{2}=0.92\right) .{ }^{5} \mathrm{y}=23.555-7.659 *$ time $+1.6315 *$ time $^{2}-0.090 * \operatorname{time}^{3}\left(\mathrm{r}^{2}=0.46\right) ;{ }^{6} \mathrm{y}=21.280-5.497 *$ time $+1.210 *$ time $^{2}-0.069 * \operatorname{time}^{3}\left(\mathrm{r}^{2}=0.35\right) ;{ }^{7} \mathrm{y}=21.925-6.841 *$ time $+1.630 * \operatorname{time}^{2}-0.096 * \operatorname{time}^{3}\left(\mathrm{r}^{2}=0.42\right) ;{ }^{8} \mathrm{y}=23.496-7.128$ $*$ time $+1.501 *$ time $^{2}-0.085 * \operatorname{time}^{3}\left(\mathrm{r}^{2}=0.56\right)$. 
In the study of Geron et al. (2013) the inclusion of increasing levels of concentrate did not alter the N-NH3 of ruminal fluid of lambs. However, there was a quadratic effect for the N-NH3 of ruminal fluid as a function of time, similar to this study.

Carvalho et al. (2011) evaluated the concentration of $\mathrm{NH}_{3}-\mathrm{N}$ receiving protein supplementation equal to $24.5 \mathrm{mg} 100 \mathrm{~mL}^{-1}$ higher to animals that received energetic supplementation $\left(10.57 \mathrm{mg} 100 \mathrm{~mL}^{-1}\right)$. The authors explained the result because the bacteria that found changes in ammonia nitrogen levels in the rumen of cattle receiving protein supplementation degrade cellulose use the ammonia for growth, thus the ammonia is a limiting factor for animals on grazing, which demonstrates the importance of protein-energy supplementation in animal feed grazing. This study the with $\mathrm{NH}_{3}-\mathrm{N}$ centration showed average of $16.24 \mathrm{mg} 100 \mathrm{~mL}^{-1}$, a value considered optimal by Sampaio et al. (2010) who consider $10 \mathrm{mg} 100 \mathrm{~mL}^{-1}$ required for increased voluntary intake of dry material for animals on grazing.

\section{Conclusion}

An increase in protein-energy supplementation improves nutrient intake and digestibility and shortens rumination time without compromising rumen parameters in lambs fed high-quality Tifton hay.

\section{References}

AGUERRE, M.; REPETTO, J. L.; PÉREZ-RUCHE, A.; MENDOZA, A.; PINACCHIO, G.; CAJARVILLE, C. Rumen $\mathrm{pH}$ and NH3-N concentration of sheep fed temperate pastures supplemented with sorghum grain. South African Journal of Animal Science, Pretória, v. 39, n. 5, p. 246-250, 2009. Supplement 1.

ALTMANN J. Observational study of behavior sampling methods. Behaviour, Leiden, v. 49, n. 3, p. 227-267, 1974.

ASSOCIATION OF OFFICIAL ANALYTICAL CHEMISTS. - AOAC. Official methods of analysis. $13^{\text {th }}$. ed. AOAC International, 2000. 989 p.

CARVALHO, D. M. G.; CABRAL, L. S.; ZERVOUDAKIS, J. T.; ARNOLDO, T. L. Q.; BENATTI, J. M. B.; KOSCHECK, J. F. W.; PIONA, M. N. M.; OLIVEIRA, A. A. Supplements for sheep maintained on marandu grass pastures. Pesquisa Agropecuária Brasileira, Brasília, v. 46, n. 2, p. 196-204, 2011.

FENNER, H. Method for determining total volatile bases in rumen fluid by steam destilation. Journal of Dairy Science, Champaign, v. 48, n. 2, p. 249-251, 1965.

GERON, L. J. V.; MEXIA, A. A.; CRISTO, R. L.; GARCIA, J.; CABRAL, L. S.; TRAUTMANN, R. J.; MARTINS, O. S.; ZEOULA, L. M. Consumo, digestibilidade dos nutrientes e características ruminais de cordeiros alimentados com níveis crescentes de concentrado em ambiente tropical no Vale do Alto Guaporé - MT. Semina: Ciências Agrárias, Londrina, v. 34, n. 5, p. 2497-2510, 2013.

GOERING, H. K.; VAN SOEST, P. J. Forage fiber analysis (apparatus, reagents, procedures and some applications). Washington: USDA Agricultural Handbook, 1970. 379 p.

ÍTAVO, C. C. B. F.; MORAIS, M. G.; COSTA, C.; ÍTAVO, L. C. V.; FRANCO, G. L.; SILVA, J. Á. da; REIS, F. A. Addition of propolis or monensin in the diet: Behavior and productivity of lambs in feedlot. Animal Feed Science and Technology, Amsterdam, v. 165, n. 3-4, p. 161-166, 2011.

ÍTAVO, L. C. V.; VALADARES FILHO, S. D. C.; SILVA, F. F. D.; VALADARES, R. F. D.; PAULINO, M. F.; ÍTAVO, C. C. B. F.; MORAES, E. H. B. K. D. Comparison of markers and collection methodology for fecal production and digesta flow estimates in bovine. Revista Brasileira de Zootecnia, Viçosa, MG, v. 31, n. 4, p 1833-1839, 2002.

JOCHIMS, F.; PIRES, C. C.; GRIEBLER, L.; BOLZAN, A. M. S.; DIAS, F. D.; GALVANI, D. B. Comportamento ingestivo e consumo de forragem por cordeiras em pastagem de milheto recebendo ou não suplemento. Revista Brasileira de Zootecnia, Viçosa, v. 39, n. 3, p. 572-581, 2010.

MACEDO JÚNIOR, G. L.; ZANINE, A. M.; BORGES, I.; PÉREZ, J. R. O. Qualidade da fibra para a dieta de ruminantes, Ciência Animal, Fortaleza, v. 17, n. 1, p. 7.17, 2007.

MARTIN, P.; BATESON, R. Recording methods. In: . Measuring behaviour: an introdutory guide. Cambridge: Cambridge University Press, cap. 5, 1993. p. $84-100$. 
MERTENS, D. R. Regulation of forage intake. In: FORAGE QUALITY, EVALUATION, AND UTILIZATION, 1994, USA. Proceedings... Wisconsin: Alliance of Crop, 1994. p. 450-493.

MERTENS, D. R.; ELY, L. O. A dynamic model of fiber digestion and passage in the ruminant for evaluating forage quality. Journal of Animal Science, Champaign, v. 49, n. 4, p. 1085-1095, 1979.

MORAIS, J. B.; SUSIN, I.; PIRES, V.; MENDES, C. Q.; OLIVEIRA JUNIOR, R. C. O.; PACKER, I. U. Ingestive behavior of sheep and nutrients digestibility of diet containing soybean hulls. Pesquisa Agropecuária Brasileira, Brasília, v. 41, n. 7, p. 1157-1164, 2006.

NATIONAL RESEARCH COUNCIL - NRC. Nutrient requirements of small rumiants, Washington, D.C.: National Academy Press, 2007. 362 p.

ØRSKOV, E. R. Protein nutrition in ruminants. 3. ed. London: Academic Press, 1982. 155 p.

POMPEU, R. C. F. F.; PINHEIRO, R. M. C.; CÂNDIDOM, M. J.; NEIVA, J. N. M.; GUERRA, J. L. L.; GONÇALVES, J. S. Behavior of sheep in Tanzania grass under intermittent stocking with four concentrate supplementation levels. Revista Brasileira de Zootecnia, Viçosa, v. 38, n. 2, p. 374-383, 2009.

RIBEIRO, M. D.; PEREIRA, J. C.; BETTERO, V. P.; QUEIROZ, A. C.; COSTA, M. G.; LEONEL, F. P. Níveis de concentrado na dieta de bezerros. Revista Brasileira de Zootecnia, Viçosa, v. 38, n. 6, p. 1133-1141, 2009.

RODRIGUES, G. H.; SUSIN, I.; PIRES, A. V.; NUSSIO, L. G.; GENTIL, R. S.; FERREIRA, E. M.; BIEHL, M. V.; RIBEIRO, M. F. Desempenho, características da carcaça, digestibilidade aparente dos nutrientes, metabolismo de nitrogênio e parâmetros ruminais de cordeiros alimentados com rações contendo polpa cítrica úmida semidespectinada e/ou polpa cítrica desidratada. Revista Brasileira de Zootecnia, Viçosa, v. 40, n. 10, p. 2252-2261, 2011.

SAMPAIO, C. B.; DETMANN, E.; PAULINO, M. F.; VALADARES FILHO, S. C.; SOUZA, M. A.; LAZZARINI, I.; PAULINO, P. V. R.; QUEIROZ, A. C. Intake and digestibility in cattle fed low-quality tropical forage and supplemented with nitrogenous compounds. Tropical Animal Health and Production, Edinburgh, v. 42, n. 7, p. 1471-1479, 2010.

SNIFFEN, C. J.; O’CONNOR, J. D.; VAN SOEST, P. J.; FOX, D. G.; RUSSELL, J. B. A net carbohydrate and protein system for evaluating cattle diets. II. Carbohydrate and protein availability. Journal of Animal Science, Champaign, v. 70, n. 11, p. 3562-3577, 1992.

VAN SOEST, P. J. Nutritional ecology of the ruminant. Ithaca: Cornell Univ. Press, 1994. 29 p.

VOLTOLINI, T. V.; MORAES, S. A. D.; ARAÚJO, G. G. L. D.; PEREIRA, L. G. R. Concentrate levels for lambs grazing on buffel grass. Revista Ciência Agronômica, Fortaleza, v. 42, n. 1, p. 216-222, 2011.

VOLTOLINI, T. V.; MOREIRA, J. N.; NOGUEIRA, D. M.; PEREIRA, L. G. R.; AZEVEDO, S. R. B.; LINS, P. R. C. Fontes proteicas no suplemento concentrado de ovinos em pastejo. Acta Scientiarum. Animal Sciences, Maringá, v. 31, n. 1, p. 61-67, 2009.

WERNERSBACH FILHO, H. L.; CAMPOS, J. M. S.; ASSIS, A. J.; VALADARES FILHO, S. C.; QUEIROZ, A. C.; VALADARES, R. F. D.; LANA, R. P. Variáveis ruminais, concentração de uréia plasmática e excreções urinárias de nitrogênio em vacas leiteiras alimentadas com concentrado processado de diferentes formas. Revista Brasileira de Zootecnia, Viçosa, v. 35, n. 3, p. 1236-1241, 2006. 